\title{
Fire occurrence zoning from local to global scale in the European Mediterranean basin: implications for multi-scale fire management and policy
}

\author{
Nikos Koutsias ${ }^{(1)}$, \\ Britta Allgöwer (2), \\ Kostas Kalabokidis ${ }^{(3)}$, \\ Giorgos Mallinis ${ }^{(4)}$, \\ Panagiotis Balatsos ${ }^{(5)}$, \\ Johann G Goldammer ${ }^{(6)}$
}

\begin{abstract}
This study proposes and evaluates a relatively new concept for fire occurrence zoning based on documented historical fire records. The proposed method creates continuous kernel density surfaces based on wildland fire ignition observations. Kernels have the advantage of directly producing density estimates that are not influenced by grid size or localization effects. Within this scheme, kernel density surfaces have been created and reclassified to construct fire occurrence zones at local to global scales in the Mediterranean Basin. Specifically, fire occurrence zones were created for the European scale (European Mediterranean Basin), national scale (Greece), regional scale (Peloponnese, Greece) and local scale (Chalkidiki, Greece). To evaluate fire occur rence zones, we compared the observed with the expected distribution of the number of fires within these zones using a Monte Carlo randomization test, finding that these numbers were statistically different in all cases. The deviations observed from the expected distributions towards the high occurrence zone indicated their successful assessment and value. In this paper, we further discuss their potential role and use for multi-scale fire management and policy in a European context.
\end{abstract}

Keywords: Fire Occurrence Zones, Kernel Density Interpolation, Local Scale, Regional Scale, National Scale, European Scale, Greece

uncertainty though (Bedia et al. 2014). Wildland fires can result in significant economic and environmental damages, degradation of ecosystem functions and services such as carbon storage, biodiversity preservation, water production and soil protection. In addition, modification of ecosystem succession due to fires can trigger land cover (land use) and landscape change (Sebastián-López et al. 2008). The magnitude of the problem of wildland fires, observed
(1) Department of Environmental and Natural Resources Management, University of Patras, G. Seferi 2, GR-30100 Agrinio (Greece); (2) Museum of Natural History, Canton of Lucerne, Kasernenplatz 6, CH-6003 Lucerne (Switzerland); (3) Department of Geography, University of the Aegean, University Hill, GR-81100 Mytilene (Greece); (4) Department of Forestry \& Management of the Environment and Natural Resources, Democritus University of Thrace, Pantazidou 193, GR-68200 Orestiada (Greece); (5) Ministry of Environment, Energy, and Climatic Change, Directorate General for Development and Protection of Forests and Natural Environment, Halkokondili 31, GR-10164, Athens (Greece); (6) Global Fire Monitoring Center (GFMC), Max Planck Institute for Chemistry, c/o Freiburg University/ United Nations University, Georges-Koehler-Allee 75, D-79110 Freiburg (Germany)

@ Nikos Koutsias (nkoutsia@upatras.gr)

Received: Nov 24, 2014 - Accepted: Sep 11, 2015

Citation: Koutsias N, Allgöwer B, Kalabokidis K, Mallinis G, Balatsos P, Goldammer JG (2015). Fire occurrence zoning from local to global scale in the European Mediterranean basin: implications for multi-scale fire management and policy. iForest 9: 195-204. - doi: 10.3832/ifor1513-008 [online 2015-11-12]

Communicated by: Davide Ascoli even in biomes like those characterizing the Mediterranean Basin, of which historically forest fires have been an integral part, raises the urgent need to develop and implement fire management strategies including effective fire prevention policies. Long-term fire danger evaluation based on robust methods is a critical component of fire prevention policies and strategies (Chuvieco et al. 2010, Oliveira et al. 2014).

The most common approach to model fire ignition patterns and designate high fire risk areas is based on the identification of environmental and socioeconomic geospatial variables that capture historical fire occurrence patterns and explain their underlying causal factors, which afterwards are assimilated into a spatially explicit "structural" or "static" index. Geospatial data layers such as fuel load, topography, road density, population, employment rates etc., are assembled in a database and integrated into a Geographic Information System (GIS) as potential factors explaining historical fire occurrence (Badia et al. 2011, Rodrigues et al. 2014).

Methodologies to identify proper parameters and models include qualitative rules for assigning risk values to different variables (Castro \& Chuvieco 1998), generalized global linear models such as linear regression (Castro \& Chuvieco 1998, SebastiánLópez et al. 2008) and logit probabilistic models (Kalabokidis et al. 2007, Vilar Del Hoyo et al. 2011), machine-learning algo- 


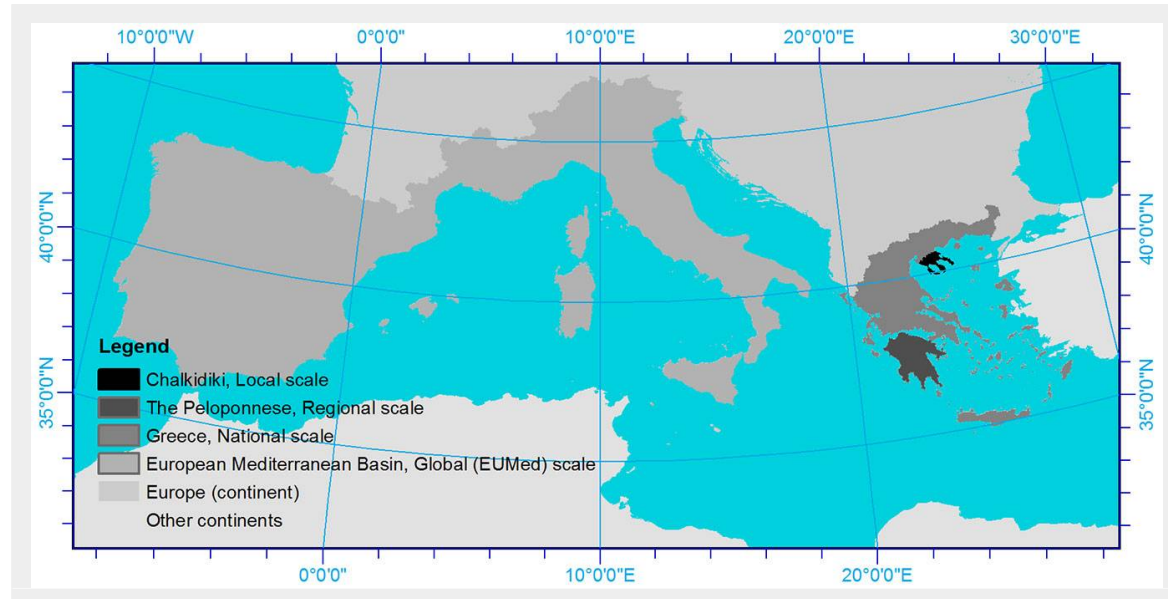

Fig. 1 - Several study areas of different magnitudes were established within the European Mediterranean Basin to capture the scale requirements of the multi-scale approach.

rithms (Catry et al. 2009, Bar Massada et al. 2013, Rodrigues \& De La Riva 2014), Classification and Regression Trees (CART - Amatulli et al. 2006), fuzzy logic (Castillo Soto 2012), as well as other advanced statistical methods such as Geographically Weighted Regression (GWR - Koutsias et al. 2010, Martínez-Fernández et al. 2013, Oliveira et al. 2014, Rodrigues et al. 2014), which allows the analysis of spatially varying relationships. Most of these approaches, however, are applied at local or regional scales, due to limitations and constraints found when gathering and updating the required geospatial data. In addition, since the relationships between these factors and fire occurrence can vary between different ecosystems and across different spatial and temporal scales (Catry et al. 2009, Xystrakis \& Koutsias 2013), different dominant fire risk drivers are identified depending on the local conditions of each study. Therefore, there are limitations to extrapolate the findings from one region to another or to generalize the results from local to global scales by combining the findings from different studies. Such efforts contain a certain degree of uncertainty due to the different methodologies and data used.

Tab. 1 - Data used to create the kernel density surfaces and data used to evaluate the fire occurrence zones for each study case.

\begin{tabular}{|c|c|c|c|c|}
\hline Study area & $\begin{array}{l}\text { Source of } \\
\text { data used }\end{array}$ & $\begin{array}{l}\text { Period covered } \\
\text { by data }\end{array}$ & $\begin{array}{l}\text { Number of } \\
\text { ignition } \\
\text { points used }\end{array}$ & $\begin{array}{c}\text { Evaluation } \\
\text { data }\end{array}$ \\
\hline $\begin{array}{l}\text { Local } \\
\text { (Chalkidiki) }\end{array}$ & $\begin{array}{l}\text { Greek National } \\
\text { Forest fire } \\
\text { database }\end{array}$ & 1985 to 1995 & 218 & $\begin{array}{c}1996 \text { and } 1997 \\
\text { fire events } \\
(29 \text { events) }\end{array}$ \\
\hline $\begin{array}{l}\text { Regional (the } \\
\text { Peloponnese) }\end{array}$ & $\begin{array}{l}\text { Greek National } \\
\text { Forest fire } \\
\text { database }\end{array}$ & 1985 to 1995 & 2720 & $\begin{array}{l}\text { EFFIS (JRC) fire } \\
\text { perimeters } \\
\text { (year 2007) }\end{array}$ \\
\hline $\begin{array}{l}\text { National } \\
\text { (Greece) }\end{array}$ & $\begin{array}{l}\text { Greek National } \\
\text { Forest fire } \\
\text { database }\end{array}$ & 1985 to 1995 & 15206 & $\begin{array}{l}1996 \text { fire events } \\
\text { (1320 events) }\end{array}$ \\
\hline $\begin{array}{l}\text { Global (EUMed - } \\
\text { European } \\
\text { Mediterranean } \\
\text { Basin) }\end{array}$ & $\begin{array}{l}\text { "SPREAD" } \\
\text { database and } \\
\text { Greek National } \\
\text { Forest Database }\end{array}$ & $\begin{array}{l}\text { 1992-2000/ } \\
/ 1985-1995\end{array}$ & $\begin{array}{c}28001 \text { community } \\
\text { centroids } \\
(211626 \text { fire } \\
\text { ignitions points) }\end{array}$ & $\begin{array}{l}\text { EFFIS }(J R C) \text { fire } \\
\text { perimeters } \\
\text { (years 2000-2010) }\end{array}$ \\
\hline
\end{tabular}

nel density interpolation has also been applied by Podur et al. (2003) to analyze the spatial patterns of lightning-caused forest fires in Ontario. Finally, in other studies the approach of kernel density interpolation has been applied as a preliminary step preceding spatial analysis of the causal factors and subsequent fire risk modeling (De La Riva et al. 2004, Amatulli et al. 2006, Vilar Del Hoyo et al. 2011).

The goal of our study is to evaluate the kernel density estimation in multi-scale (i.e., local to global scale) fire occurrence zoning in the Mediterranean Basin. Specifically, fire occurrence zones are presented and evaluated for the local (Chalkidiki, Greece), regional (Peloponnese, Greece), national (Greece), and European scale (European Mediterranean Basin). The paper focuses on the statistical evaluation of fire occurrence zones at multiple spatial scales and the discussion of their value and use for multi-scale fire management and fire policy.

Amita positional inaccuracies or uncertainties of fire ignition points is to adopt administrative districts such as counties or municipalities (Lee et al. 2006, Chen 2007, Martínez et al. 2009) or map tiles (Vazquez \& Moreno 1998) as the basic spatial processing unit. However, studies based on aggregated data are vulnerable to the Modifiable Areal Unit Problem (MAUP - Openshaw 1984, Bailey \& Gatrell 1995), since the aggregation scheme used is to some extent arbitrary and modifiable (Jelinski \& Wu 1996). Additionally, aggregated statistics may lead to partial information loss (Perry \& Dixon 2002).

Fire occurrence zones can be created by using kernel densities (Worton 1989, Bailey \& Gatrell 1995, Seaman \& Powell 1996) in an attempt to overcome the loss of information from aggregation constraints and to address the inherent positional inaccuracies of fire ignition points. The kernel density concept was originally introduced within the framework of fire occurrence by Koutsias et al. $(2002,2004)$ to overcome the problems arising from the positional uncertainty of historical fire records. Ker-

\section{Materials and methods}

\section{Study areas and wildland fire data}

Several study areas were established within the European Mediterranean Basin (Fig. 1) to cover the requirements of the multi-scale approach followed in our study. For each study case different data where used to create and evaluate the kernel density surfaces summarized in Tab. 1. For all Greek study areas the fire database used to create the kernel density surfaces consists of the fire ignition points recorded between 1985 and 1995 in Greece, when a total of 15206 fire events were registered by the forest authorities. To evaluate the kernel density surfaces on the national level in Greece, we used the fire ignition points of 1996 (one year later than those used to create the kernel density surfaces) when 1320 fire events were registered. For the regional level in the Peloponnese, the 2007 fire perimeters (12 years later than those used to create the kernel density surfaces) were used, provided by the European Forest Fire Information System (EFFIS) of the European Commission Joint Research Centre (JRC). At EUMed scale we used the kernel density surfaces that were created within the EU research project "SPREAD", using fires that occurred within the period of 1992-2000 and made available using community centroids (number of fires per community), with the exception of Greece where the already mentioned $x$ and $y$ coordinates for 1985-1995 were available and used. To evaluate the kernel density surfaces at EUMed scale we used the fire perimeters of 2000-2010 provided by the JRC. For all cases the evaluation data were either point observations or fire perimeters that occurred in the subsequent years after those used to create the kernel density surfaces, in order to avoid over fitting during the evaluation phase, when the same data are used for both 
training and evaluation.

At EUMed scale fire statistics as reported by the five Mediterranean countries (Portugal, Spain, France, Italy and Greece) present some incompatibilities due to different methodologies followed on fire reporting. These different applied methodologies result in a different total number of fires per year (and therefore different fire densities) within each country which cannot be justified from differences in country's fire regime. A standardization of the density values within each country before merging them was considered to avoid over- or under-estimation within and between the countries, with the disadvantage of the unification of the density values. The main reason underlying such decision was the quite different number of ignition points available for each country that mainly reflects the different methodologies used to report fire ignitions, and not the actual events occurred based on the fire regime of each country.

\section{Methodology}

\section{The kernel density approach}

For all the study cases the kernel density interpolation was applied keeping the same concept whenever possible, but using different data and scales. The fixed mode approach was adopted when the original fire data were provided in $x$ and $y$ coordinates, in order to keep the smoothing parameter of the kernel constant over the entire study area. In this case the mean nearest distance of fire ignition points was considered to define the size of the bandwidth. When the fire data were aggregated to community centroids the adaptive kernel density interpolation approach was used, as this allows variation of the kernel size according to the concentration of the interpolated points. This enables us to deal with the spatial arrangement of commu- nity centroids that is not constant throughout the whole extent of the study area. In some areas the community density is high because the geographic extent of the communities is small, while in others the opposite holds. Therefore, over- or under-estimation of fire occurrence is likely.

The kernel density surfaces were rescaled with the criterion of "equal area" to create four equal area fire occurrence zones for Greece, and five for the EUMed scale.

\section{Evaluation of fire occurrence zones of kernel density surfaces}

The expected number of fires occurring under complete spatial randomness would be $25 \%$ or $20 \%$ in each zone, since each fire occurrence zone corresponds to $1 / 4$ (all Greek study cases) or $1 / 5$ (EUMed scale) of the total area, respectively. Deviations from this expected distribution towards the high occurrence zones indicate a successful assessment of fire occurrence zones. The estimated fire occurrence zones created based on the kernel density surfaces of both the fire ignition points and the control points, were evaluated using the fire perimeters of the year 2007 provided by the JRC, and the fire ignition points that occurred in 1996 in Greece. To statistically compare the results between the different approaches of kernel density interpolation, we applied a Monte Carlo randomization test (Moreira et al. 2001, Bajocco \& Ricotta 2008, Conedera et al. 2010), without considering any criteria different from complete randomness using a Microsoft Excel $^{\circledR}$ macro (Pezzatti et al. 2009). The wildfires were randomly reassigned to each class of the geographical layer so that the probability of assignment to each class is equal to the relative extent of that class over the entire area (Bajocco \& Ricotta 2008). Finally, we estimated the resource selection index defined as the ratio of the observed over available to burn ratio. A resource selection index $>1$ suggests positive fire selectivity (preference), while an index $<1$ suggests negative fire selectivity (avoidance - Manly et al. 2010).

\section{Results}

\section{Applying the kernel density approach}

\section{Chalkidiki (local scale)}

The fire occurrence zones at local scale in Chalkidiki, Greece (Fig. 2), based on the kernel density interpolation, were taken from the study by Koutsias et al. (2004), where the authors introduced the kernel density concept in wildland fire occurrence and risk mapping. In this study, density surfaces were created and used to delineate zones of fire occurrence at landscape level by smoothing the influence of the individual fire ignition point.

\section{The Peloponnese (regional scale)}

The fire occurrence zones at regional scale in the Peloponnese, Greece (Fig. 3), based on the kernel density interpolation, were taken from the kernel density map of Greece which is the result of the work by Koutsias et al. (2005) and Koutsias et al. (2014). The kernel density estimates were rescaled with the criterion of equal area to create four equal area fire occurrence zones within the Peloponnese.

\section{Greece (national scale)}

At national scale, the fire occurrence zones (Fig. 4) based on the kernel density interpolation, result from the work of Koutsias et al. (2005) and Koutsias et al. (2014). In this study, we applied the kernel density interpolation approach on wildland fire ignition points occurring in Greece from 1985 to 1995 . We applied different kernel sizes using the fixed approach, while the kernel size was based on the nearest neighbor distance of the wildland fire igni-

Fig. 2 - Fire occurrence zones based on kernel density surfaces at local scale in Chakidiki, Greece. The yellow dots are the ignition points used in the analysis (see Tab. 1).

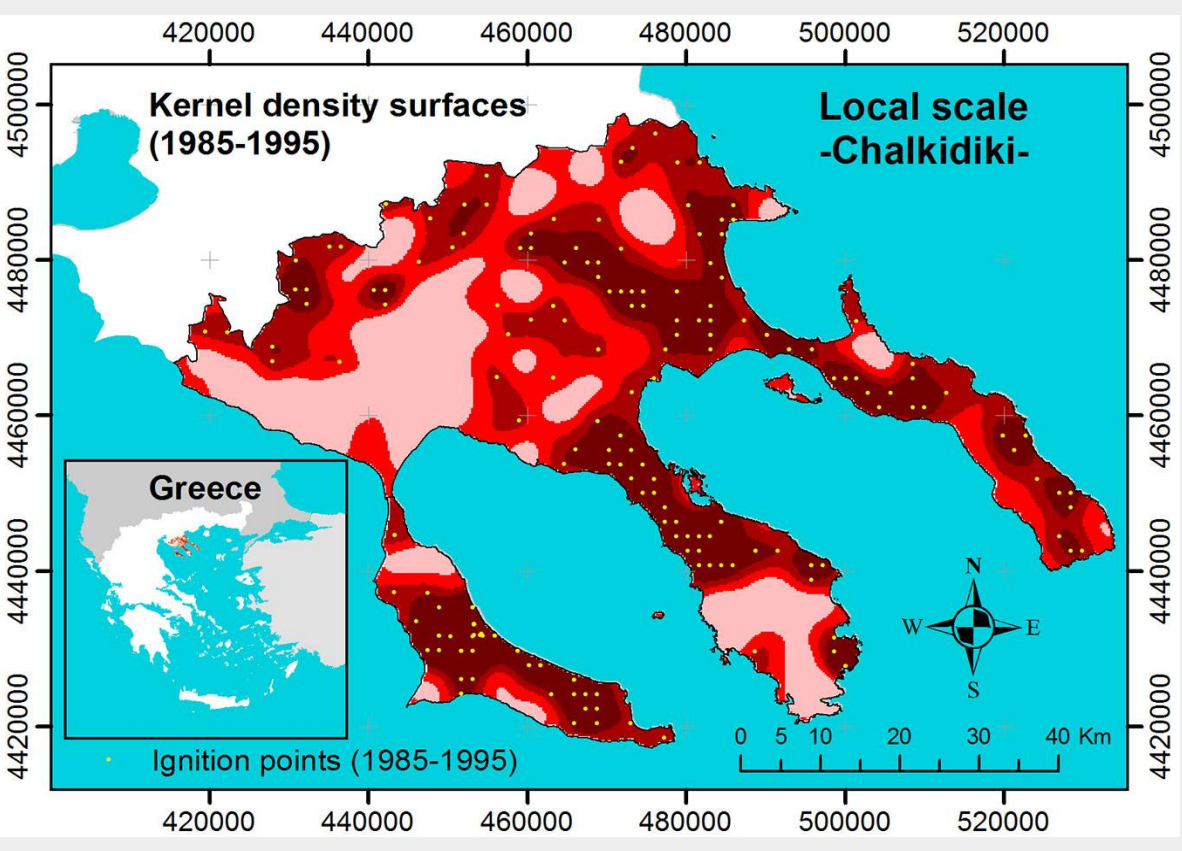




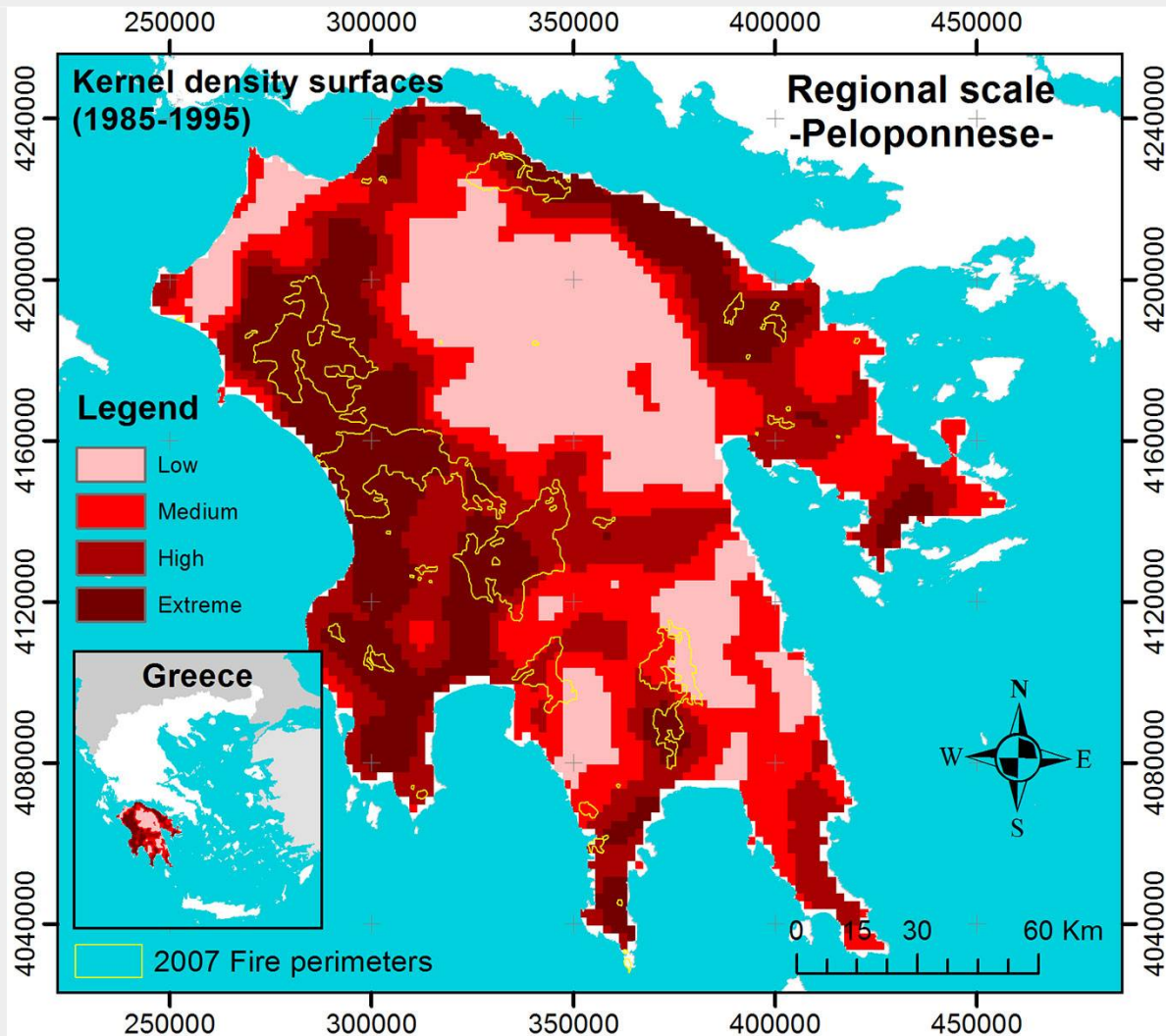

Fig. 3 - Fire occurrence zones based on kernel density surfaces at regional scale in the Peloponnese, Greece.

tion points. Apart from the kernel density of fire ignition points, we applied the method to control points created based on different buffer zones established around the fire ignition points. By applying a random sampling scheme excluding certain buffer zones around fire ignition points
(Kalabokidis et al. 2007), we adopted a sampling scheme to avoid creating control points that would fall on the same or nearby fire ignition points. The buffer zones were chosen based on the mean nearest neighbor distance of fire ignition points.

\section{European Mediterranean Basin (Global} EUMed scale)

The fire occurrence zones at EUMed scale (Fig. 5), based on the kernel density interpolation, result from the EU research project SPREAD (Allgöwer et al. 2004). The aim of this study was to define large-scale

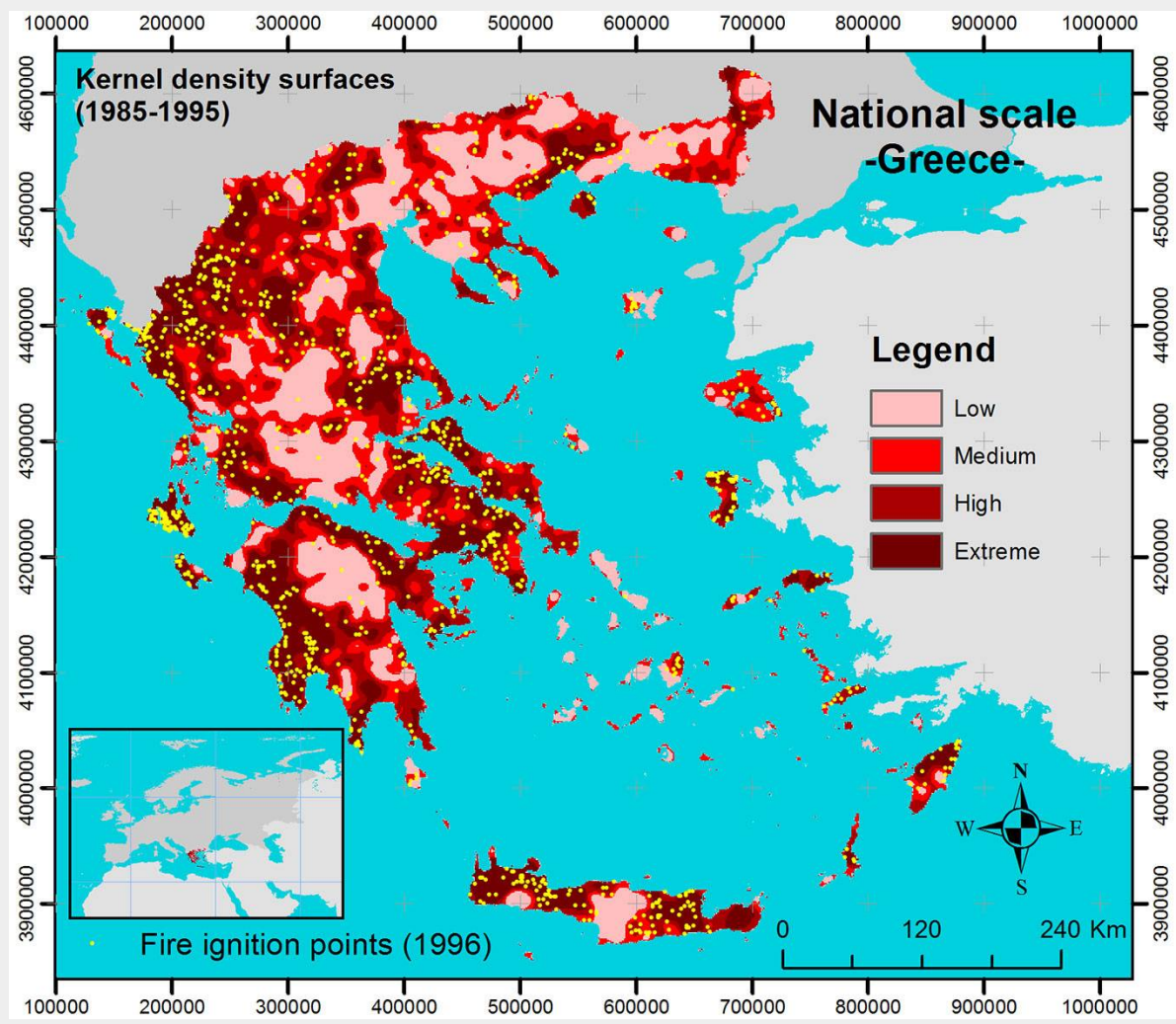


Fig. 5 - Fire occurrence zones based on kernel density surfaces at European/global scale in the European Mediterranean Basin.
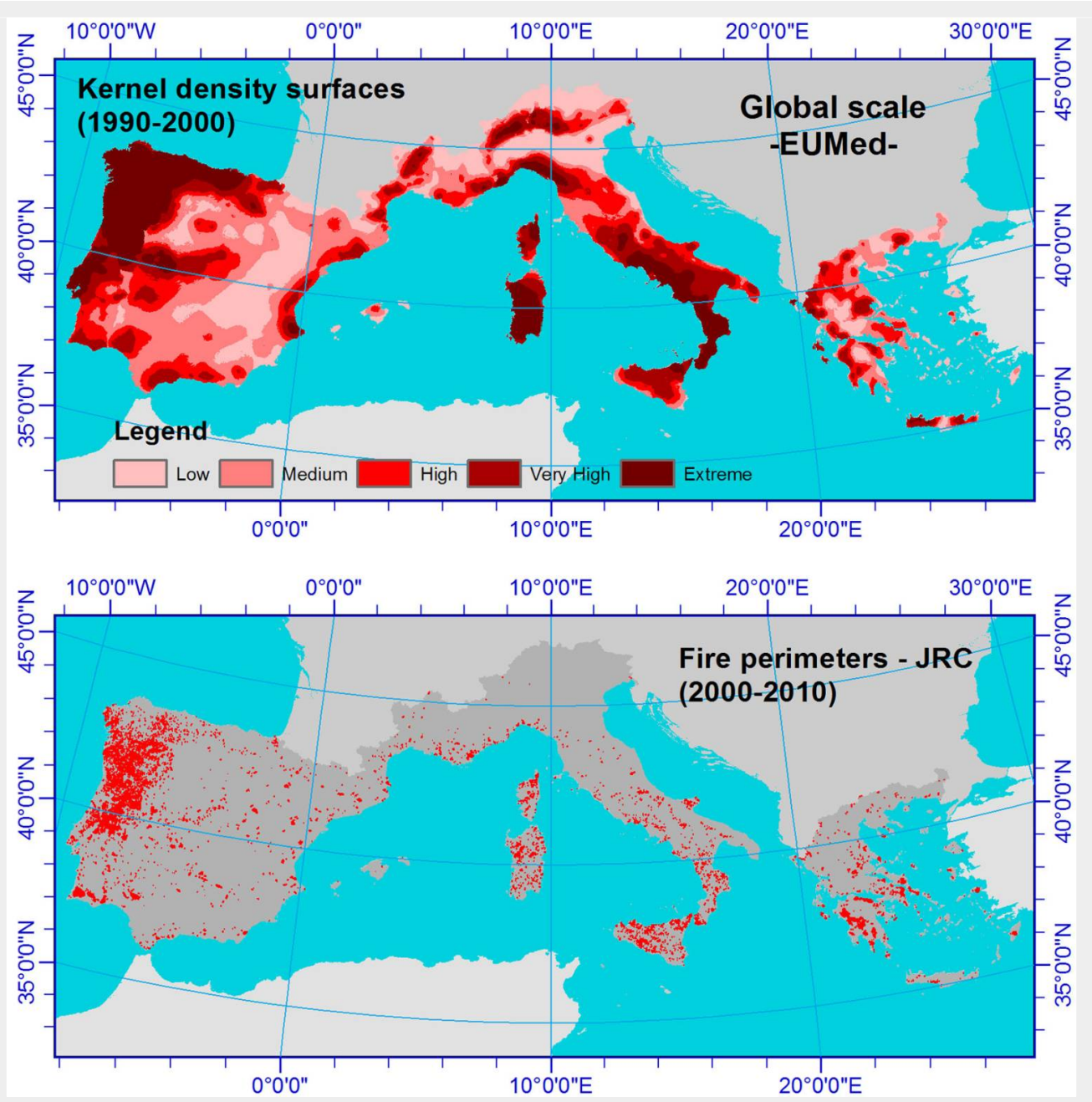

wildland fire occurrence patterns and to identify "fire hot-spot areas" in southern Europe by using fire ignition observations aggregated at community level. An adaptive kernel density interpolation approach was followed, in which the (geographically defined) community centroids represent the "spatial anchor points", and where the number of fires per community was used as the intensity variable for the kernel density estimation calculations. After several experiments, locally varying bandwidth sizes proved to perform best, and the interpolation of 10 community centroids under the same kernel showed a reasonable variability in the resulting density surfaces.

\section{Evaluation of fire occurrence zones}

\section{The Peloponnese (regional scale)}

The fire scars of 2007, the year with the highest total of burned areas ever recorded in Greece (Koutsias et al. 2012), were overlaid onto the fire occurrence zones (Fig. 3), and the distribution observed was estimated and compared with its random expectation (Fig. 6). The observed distribution of fire occurrence zone values was statistically significantly different to the expected distribution under a complete spatially random process. For the occurrence zone value of 4 (very high) the percentage was $65.68 \%$ (Fig. 3), much higher than and statistically significantly different to the expected one of $24.69 \%$. The resource selection index is higher than the threshold value of 1 only in the case of the highest risk zone (2.66), denoting positive selectivity (preference) of the fires, while all the others have values below 1 , denoting negative selectivity (avoidance) of the fires.

\section{Greece (national scale)}

The wildfire ignition points of 1996, one year after the period 1985-1995 used to run the kernel density interpolation, were overlaid onto the fire occurrence zones (Fig. 4) and the distribution observed was estimated and compared to the expected one (Fig. 6). The observed distribution of fire occurrence zone values was statistically significantly different to the expected one under a complete spatially random process. Again, for occurrence zone 4 (very high) the percentage was $63.79 \%$ (Fig. 4), much higher than and statistically significantly different to the expected one of $24.98 \%$. The resource selection index was higher than the threshold value of 1 only in the case of the highest risk zone (2.55), denoting positive selectivity (preference) of the fires, while all the others presented values below 1, denoting negative selectivity (avoidance) of the fires.

\section{European Mediterranean Basin (Global EUMed scale)}

The fire perimeters of 2000-2010, one decade after the period used to run the kernel density interpolation, were overlaid onto the fire occurrence zones (Fig. 5). The observed distribution was estimated and compared with the random expectation (Fig. 6). The observed distribution of fire occurrence zone values was statistically significantly different to the expected distribution under a complete spatially random process, since especially for occurrence zone 5 (extreme) the percentage was $47.65 \%$ (Fig. 5), much higher than and statistically significantly different to the expected one of $20 \%$ (actually $16.27 \%$ ). The resource selection index was higher than the threshold value of 1 only for the extreme (2.93) and very high zones (1.52), thus denoting positive selectivity (preference) of the fires. The other zones presented values below 1 , thus denoting negative selectivity (avoidance) of the fires.

\section{Discussion}

As the recent observed changes in wildland fire regimes are increasingly affecting human and ecological resources, a need 



Greece
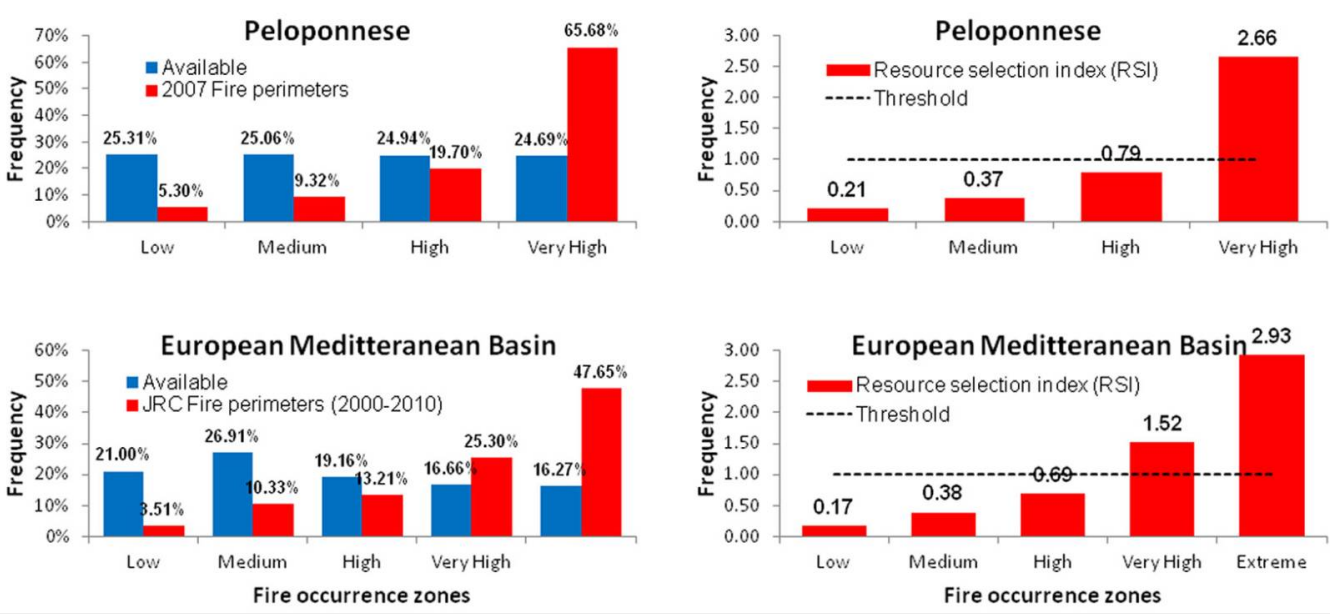

Fig. 6 - (left panel) The observed distribution of fire parameters (ignition points, fire perimeters) was compared to the expected one at the different scales of analysis using a Monte Carlo randomization test. (right panel) A resource selection index, defined as the ratio of the observed over available to burn ratio, was estimated and used to show the fire selectivity in the different fire occurrence zones. For more details, see the text. has arisen to develop quantitative strategies and approaches for fire risk management, including methods for risk assessment (exposure and effects) and mitigation of fire effects (Miller \& Ager 2013, Salis et al. 2013b, Viedma et al. 2015). The effects of fire on landscape may vary from region to region because of differences in regeneration patterns among main land cover types, topographic constraints and local fire histories (Viedma 2008, Bradstock et al. 2010). Despite the fact that the majority of fires have human causes, fire ecology models often fail to integrate human land and fire use patterns as, for example, most savanna ecology models (Laris 2011). Additionally, fire incidence depends not only on structural factors such as the type of vegetation or climate conditions, but also on spatial factors (Vázquez \& Moreno 2001). In general, variables defining landscape composition or proximity to human influence (Moreno et al. 2011), along with landscape structure (Viedma et al. 2009) and human activities such as agriculture and construction related to development projects, are also important underlying factors of fire risk in the Mediterranean (Martínez et al. 2009), while their spatial relationships may vary (Koutsias et al. 2010). Under this perspective fire-fighting organizations design and implement operational projects to successfully prevent, forecast and suppress forest fires. Many factors such as specialized requirements and personnel, labor, availability of necessary means and usually limited economic resources compete to optimize such efforts and actions. Wildland fire occurrence zoning helps to orient the managers a priori towards the proper civil protection actions, while it might be a strategic operational advantage for the proper development of a Decision Support System (DSS).

At the local/regional scale, the proposed method could be used to design prevention planning programs to reduce the risk of fire ignition. Fire occurrence zones could be used to guide and prioritize fuel treatments across fire-prone landscapes and resources. Fuel treatments such as prescribed burning and thinning may reduce the quantity, depth and vertical or horizontal continuity of fuels, changing surface fire spread rates and reducing the likelihood of crowning fire behavior (Cochrane et al. 2012). However, as stated by Fernandes et al. (2013), the adoption of prescribed burning in the Mediterranean Basin has been slow, uneven and inconsistent. Its development is constrained by cultural and socioeconomic factors as well as by specific factors related to demography, land use, and landscape structure. Additionally, fire occurrence zones could be used to identify areas where fine-scale modeling of fire spread dynamics should be considered, and identify areas where mitigation strate- gies limit fire intensity and spread (Salis et al. 2013a). Furthermore, fire occurrence zones could be efficiently used to simulate the effectiveness of the initial attack, to allocate available fire fighting resources and to coordinate fire dispatching levels, staff schedules and deployment, and linebuilding tactics (Fried et al. 2006). Kernelbased occurrence zones could be adopted in different landscapes to allocate fuel breaks, reduce resource costs and maximize their efficiency in controlling wildfire spread (Syphard et al. 2011). Additionally, fire occurrence zones could be used to highlight areas where the development of ground fire surveillance and early-detection systems is crucial for forest protection and instant forest fire suppression (Tsiourlis et al. 2009).

Finally, at regional scale, fire occurrence zones may prove very helpful when approaching the wildland-urban interface problem which is very common in Mediterranean countries. Fire occurrence zones can be overlaid over urban and rural designated areas, thereby defining critical regions where the wildland-urban as well as the wildland-rural interface become a potential problem for society as far as forest fires are concerned (Rodrigues et al. 2014). As stated by Koutsias et al. (2012), forest fires in the wildland-urban interface have become very common in Europe as population and human infrastructure facilities are 
disseminated throughout forested zones, especially in the vicinity of large cities and tourist resorts (Viegas et al. 2003), and also due to afforestation of abandoned agricultural lands located close to settlements (Galiana-Martin et al. 2011). Major social and economic changes in land use have affected both the wildland-rural interface and the wildland-urban interface resulting in increased quantities of biomass (fuel), higher exposure to human-induced fire, and conflicts (Pérez et al. 2003, Massada et al. 2009, Galiana-Martin et al. 2011, Moreira et al. 2011, Fernandes 2013). At the national scale, kernel density surfaces could be used as a standard procedure for more reliable and site-specific early warning systems of fire danger estimation in countries that differ in physical and socioeconomic conditions (Viegas et al. 1999, Thompson et al. 2011). In addition, fire occurrence zoning may offer a strategic operational advantage for the proper development of a DSS (Kalabokidis et al. 2012), since such efforts can be applied with spatial and temporal priorities within fire-prone regions. Thus, reduction of the necessary costs and maximization of the benefits and outcomes (Rideout \& Omi 1990) can be addressed more adequately (cost/benefit analysis). Another asset of kernel-based occurrence zoning is that the distribution and mapping of fire risk and behavior (Palaiologou et al. 2013) could be used for spatial allocation of human and economic resources throughout the year for fire program planning and regional development, as well as for implementing environmental policies, law enforcement, educational activities and advanced engineering of fire prevention at national levels (Pyne et al. 1996). Based on fire occurrence zoning, hazard mitigation and monitoring programs may also be revised using alternative scenarios and focus on identified and educated objectives and impacts. Overall, wildland fire occurrence zoning has the potential to orient a priori national land-management authorities towards optimal actions for emergency risk management and civil protection.

European scale policies on forest fires require comprehension of the underlying mechanisms and relationships between biophysical factors, landscape characteristics, people, and wildland fires within and among the different countries. A pan-European approach also requires methods that ignore national boundaries to more clearly identify European patterns of similarities and differences. Lack of complete and comparable data, along with the complexity of factors influencing fire occurrence and risk, impose limitations to the systematic investigation of long-term fire occurrence and risk when using modeling approaches based on physical, socioeconomic and demographic explanatory variables (Oliveira et al. 2012). The kernel zoning approach can be used to create fire occurrence zones on a European level and used to help design prevention policies adapted to the socioeconomic, cultural and environmental conditions of each region and nation (Ganteaume et al. 2013).

Establishment of robust fire occurrence and fire risk zones is a necessary basic step to develop and coordinate effective European response mechanisms. A transboundary spatially explicit risk estimate may enhance cooperation between the European member states and the implementation of best practices in forest fire prevention and fire fighting. Nowadays, there is a need for information on fire risk that could support integrated and long-term approaches for wildland fire management in Europe. Development of common European approaches and policies on fire management is required due to the transboundary effects of wildland fires, the existence of many diverse environmental causes and consequences related to this risk which require coordination at European Union scale (Montiel-Molina 2013). Currently, the European Forest Fire Information System (EFFIS) which is a modular DSS that monitors forest fires at a continental scale and delivers real-time, multi-dimensional data (McInerney et al. 2013), justifies the need for coordinated common approaches to fire management in Europe. Since its establishment, EFFIS, whose objective is to provide accurate data to assess and mitigate the impacts of wildfire events on society and the environment (Mclnerney et al. 2013), has influenced the further development of EU environmental policies on forest protection (San-Miguel-Ayanz et al. 2013).

In summary, alternative and/or complementary to some of the classical fire occurrence and fire risk assessment methods, we propose a fire occurrence zoning approach at multiple spatio-temporal scales and extents in order to identify homogeneous areas of similar fire occurrence, based solely on documented historical fire observations. At national or global scales the proposed methodology could allow rapid identification and targeting of highrisk areas to develop and implement detailed fire risk models. Furthermore, these fire occurrence zones could be one of the basic inputs for generating mechanistic hypotheses and constructing large-scale fire risk maps aimed at more reliable spatial and temporal prediction of wildland fire occurrence. Fire occurrence zoning based solely on documented historical fire occurrence records is more straightforward and less demanding on statistical assumptions compared to model building approaches.

Finally, two important issues of kernel density are worth to be discussed: (i) the mode of the kernel, i.e., fixed versus adaptive mode; and (ii) the size of the smoothing parameter of the kernel.

To implement kernel density estimation in wildland fire occurrence, the fixed mode approach can be adopted to keep the smoothing parameter of the kernel con- stant over the entire study area for avoiding different treatments of the point observations over areas with different point density. On the other side, when fire data are aggregated to community centroids the adaptive kernel density interpolation approach may be more useful, as this allows variation of the kernel size according to the density of the interpolated points. This enables the different treatment of the point observations over areas with different point density according to the spatial arrangement of community centroids that is not constant throughout the whole study area. Indeed, in some areas the community density is high because the geographic extent of the communities is small, while in others the opposite holds. Therefore, over- or under-estimation of fire occurrence is likely.

In addition to the choice of the kernel type, the choice of the smoothing parameter is crucial, since it controls the amount of variation of estimates (Worton 1989). To define the size of the bandwidth, the mean nearest distance of fire ignition points may be considered. The association of the size of the smoothing parameter of the kernel to the mean nearest distance is reasonable, since the amount of point observations that has to be interpolated is related to the information content. If the sample size is large, which corresponds to more informative datasets, then a finer interval resolution would be more suitable to avoid over-smoothing and loss of the variability in the estimates. For small size samples, which correspond to less informative datasets, a large bandwidth would be more appropriate, since a fine interval would lead to density estimations that may be perceived as nothing more than a random variation. The size of the smoothing parameter also defines the level of scale of the estimates; large intervals diminish local variability and their estimates are associated with global patterns, while narrow intervals preserve data variability and are associated to local patterns (Koutsias et al. 2004).

\section{Conclusions and future prospects}

This study proposes and evaluates a relatively new concept for creating forest fire occurrence zones at multiple scales based on documented historical fire records. An attractive feature of the proposed concept is the consistency it provides among different scales in terms of both methods and data (Calkin et al. 2011). The present study demonstrates that application of the kernel density technique may improve the simple visualization-oriented use (De La Riva et al. 2004, Koutsias et al. 2004, Amatulli et al. 2007), thus becoming a useful analytical tool for fire risk management. One drawback of our approach, however, is that it considers only documented fire history data to create fire occurrence zones, and therefore does not capture any changes that might occur in fire drivers and under- 
lying causal factors, such as those that might be induced either by future climate change or other land cover changes due to human activity, which is very common in the Euro-Mediterranean region (Santini et al. 2014).

Future work should explore the assessment of fire occurrence zones considering alternative scenarios such as fire size (e.g., only large recorded wildfires), fire causal factors (e.g., lightning), and other parameters of the fire event (e.g., time of ignition). This information could help fire-managers to identify areas where ad hoc, effective fire prevention measures should be introduced or, alternatively, more detailed, large-scale fire risk analysis and modeling should be applied.

\section{Acknowledgements}

The kernel density zones of the European Mediterranean Basin were created within the EC project "Forest Fire Spread and Mitigation (SPREAD)", EC-Contract Nr. EVG1CT-2001-00027, and the Federal Office for Education and Science of Switzerland (BBW), BBW-Contract Nr. 01.0138. We acknowledge the European Forest Fire Information System (EFFIS) of the European Commission Joint Research Centre, the Hellenic Fire Brigade and the Hellenic Forest Service for providing wildland fire data used in our study.

\section{References}

Allgöwer B, Koutsias N, Benvenuti M, Blanchi R, Bonora L, Chuvieco E, Conese C, Godfrin V, Heikkila T, Kauppinen T, Martín P, Martínez J, Martínez Fernandez J, Ribeiro L-M, Viegas DX (2004). Fire risk and human factors (III), The human factor in fire occurrence (Part 3), Fire Occurrence Analysis Methods (Part 3), The Wildland Urban Interface (WUI) (Part 2). Deliverable no. 143, SPREAD Project, pp. 129.

Amatulli G, Peréz-Cabello F, De La Riva J (2007). Mapping lightning/human-caused wildfires occurrence under ignition point location uncertainty. Ecological Modelling 200 (3-4): 321-333. doi: 10.1016/j.ecolmodel.2006.08.001

Amatulli G, Rodrigues MJ, Trombetti M, Lovreglio R (2006). Assessing long-term fire risk at local scale by means of decision tree technique. Journal of Geophysical Research G: Biogeosciences 111 (4). - doi: 10.1029/2005JG000133 Badia A, Serra P, Modugno S (2011). Identifying dynamics of fire ignition probabilities in two representative Mediterranean wildland-urban interface areas. Applied Geography 31 (3): 930940. - doi: 10.1016/j.apgeog.2011.01.016

Bailey TC, Gatrell AC (1995). Interactive spatial data analysis ( $1^{\text {st }}$ edn). Longman Scientific and Technical, Essex, UK, pp. 413. [online] URL: http://www.personal.psu.edu/faculty/f/k/fkw/rs oc597/Introduction.pdf

Bajocco S, Ricotta C (2008). Evidence of selective burning in Sardinia (Italy): which land-cover classes do wildfires prefer? Landscape Ecology 23 (2): 241-248. - doi: 10.1007/s10980-007-9176-5 Bar Massada A, Syphard AD, Stewart SI, Radeloff VC (2013). Wildfire ignition-distribution modelling: a comparative study in the Huron-Manis- tee National Forest, Michigan, USA. International Journal of Wildland Fire 22 (2): 174-183. doi: 10.1071/WF11178

Bedia J, Herrera S, Camia A, Moreno JM, Gutiérrez JM (2014). Forest fire danger projections in the Mediterranean using ENSEMBLES regional climate change scenarios. Climatic Change 122 (1-2): 185-199. - doi: 10.1007/s10584-013-1005-z Bradstock RA, Hammill KA, Collins L, Price O (2010). Effects of weather, fuel and terrain on fire severity in topographically diverse landscapes of south-eastern Australia. Landscape Ecology 25 (4): 607-619. - doi: 10.1007/s10980oog-9443-8

Calkin DE, Ager AA, Thompson MP, Finney MA, Lee DC, Quigley TM, McHugh CW, Riley $\mathrm{KL}$, Gilbertson-Day JM (2011). A comparative risk assessment framework for wildland fire management: the 2010 cohesive strategy science report. General Technical Report RMRS-GTR 262, USDA Forest Service, Fort Collins, CO, USA, pp. 1-63.

Castillo Soto ME (2012). The identification and assessment of areas at risk of forest fire using fuzzy methodology. Applied Geography 35 (12): 199-207. - doi: 10.1016/j.apgeog.2012.07.001 Castro R, Chuvieco E (1998). Modeling forest fire danger from geographic information systems. Geocarto International 13 (1): 15-23. - doi: 10.1080/10106049809354624

Catry FX, Rego FC, Bação FL, Moreira F (2009). Modeling and mapping wildfire ignition risk in Portugal. International Journal of Wildland Fire 18 (8): 921-931. - doi: 10.1071/WF07123

Chen X (2007). Spatial pattern of wildfire occurrences in Alabama, USA. International Journal of Environmental Studies 64 (2): 229-242. - doi: 10.1080/00207230701257135

Chuvieco E, Aguado I, Yebra M, Nieto H, Salas J, Martín MP, Vilar L, Martínez J, Martín S, Ibarra P, De La Riva J, Baeza J, Rodríguez F, Molina JR, Herrera MA, Zamora R (2010). Development of a framework for fire risk assessment using remote sensing and geographic information system technologies. Ecological Modelling 221 (1): 46-58. - doi: 10.1016/j.ecolmodel.2008.11.017 Cochrane MA, Moran CJ, Wimberly MC, Baer AD, Finney MA, Beckendorf KL, Eidenshink J, Zhu Z (2012). Estimation of wildfire size and risk changes due to fuels treatments. International Journal of Wildland Fire 21 (4): 357-367. - doi: 10.1071/WF11079

Conedera M, Torriani D, Neff C, Ricotta C, Bajocco S, Pezzatti GB (2010). Using Monte Carlo simulations to estimate relative fire ignition danger in a low-to-medium fire-prone region. Forest Ecology and Management 261 (12): 21792187. - doi: 10.1016/j.foreco.2010.08.013

De La Riva J, Pérez-Cabello F, Lana-Renault N, Koutsias N (2004). Mapping forest fire occurrence at a regional scale. Remote Sensing of Environment 92 (3): 363-369. - doi: 10.1016/j.rse. 2004.06.022

Fernandes PM (2013). Fire-smart management of forest landscapes in the Mediterranean basin under global change. Landscape and Urban Planning 110: 175-182. - doi: 10.1016/j.landurb plan.2012.10.014

Fernandes PM, Davies GM, Ascoli D, Fernández C, Moreira F, Rigolot E, Stoof CR, Vega JA, Molina D (2013). Prescribed burning in southern
Europe: developing fire management in a dynamic landscape. Frontiers in Ecology and the Environment 11 (s1): e4-e14. - doi: 10.189o/ 120298

Fried JS, Gilless JK, Spero J (2006). Analysing initial attack on wildland fires using stochastic simulation. International Journal of Wildland Fire 15 (1): 137-146. - doi: 10.1071/WF05027 Galiana-Martin L, Herrero G, Solana J (2011). A wildland-urban interface typology for forest fire risk management in Mediterranean areas. Landscape Research 36 (2): 151-171. - doi: 10.1080/01426397.2010.549218

Ganteaume A, Camia A, Jappiot M, San-MiguelAyanz J, Long-Fournel M, Lampin C (2013). A review of the main driving factors of forest fire ignition over Europe. Environmental Management 51 (3): 651-662. - doi: 10.1007/s00267-0129961-z

Harris S, Nicholls N, Tapper N (2013). Forecasting fire activity in Victoria, Australia, using antecedent climate variables and ENSO indices. International Journal of Wildland Fire 23 (2): 173-184. - doi: 10.1071/WF13024

Jelinski DE, Wu J (1996). The modifiable areal unit problem and implications for landscape ecology. Landscape Ecology 11 (3): 129-140. doi: $10.1007 / B F 02447512$

Kalabokidis K, Xanthopoulos G, Moore P, Caballero D, Kallos G, Llorens J, Roussou O, Vasilakos C (2012). Decision support system for forest fire protection in the Euro-Mediterranean region. European Journal of Forest Research 131 (3): 597-608. - doi: 10.1007/s10342-011-0534-0 Kalabokidis KD, Koutsias N, Konstantinidis P, Vasilakos C (2007). Multivariate analysis of landscape wildfire dynamics in a Mediterranean ecosystem of Greece. Area 39 (3): 392-402. doi: 10.1111/j.1475-4762.2007.00756.x

Koutsias N, Kalabokidis KD, Allgöwer B (2002). Fire occurrence patterns at landscape level: beyond positional accuracy of ignition points with kernel density estimation methods. In: Proceedings of the "2002 World Conference on Natural Resources Modeling - Modeling Natural and Biotic Resources in a Changing Planet". Sigri (Lesbos, Greece) 23-26 June 2002 [poster]. Koutsias N, Kalabokidis KD, Allgöwer B (2004). Fire occurrence patterns at landscape level: beyond positional accuracy of ignition points with kernel density estimation methods. Natural Resource Modeling 17 (4): 359-375. - doi: 10.1111/j.1939-7445.2004.tboo141.x

Koutsias N, Karteris M, Balatsos P, Kalabokidis KD (2005). Strategic planning approach in wildland fire danger zoning: a geographical perspective with historical fire observations. Geographies 10: 62-79.

Koutsias N, Martínez-Fernández J, Allgower B (2010). Do factors causing wildfires vary in space? Evidence from geographically weighted regression. GIScience and Remote Sensing 47 (2): 221-240. - doi: 10.2747/1548-1603.47.2.221

Koutsias N, Arianoutsou M, Kallimanis AS, Mallinis G, Halley JM, Dimopoulos P (2012). Where did the fires burn in Peloponnisos, Greece the summer of 2007? Evidence for a synergy of fuel and weather. Agricultural and Forest Meteorology 156: 41-53. - doi: 10.1016/j.agrformet.2011. 12.006

Koutsias N, Xanthopoulos G, Founda D, Xystrakis 
F, Nioti F, Pleniou M, Mallinis G, Arianoutsou M (2013). On the relationships between forest fires and weather conditions in Greece from long-term national observations (1894-2010). International Journal of Wildland Fire 22 (4): 493-507. - doi: 10.1071/WF12003

Koutsias N, Balatsos P, Kalabokidis KD (2014). Fire occurrence zones: kernel density estimation of historical wildfire ignitions at the national level, Greece. Journal of Maps 10 (4): 630-639. - doi: 10.1080/17445647.2014.908750

Laris P (2011). Humanizing savanna biogeography: linking human practices with ecological patterns in a frequently burned savanna of southern Mali. Annals of the Association of American Geographers 101 (5): 1-22. - doi: 10.1080/00045608.2011.560063

Lee B, Park PS, Chung J (2006). Temporal and spatial characteristics of forest fires in South Korea between 1970 and 2003. International Journal of Wildland Fire 15 (3): 389-396. - doi: 10.1071/WF05090

Manly BF, McDonald TL, Thomas DL, Erickson WP (2010). Resource selection by animals: statistical design and analysis for field studies. Springer, New York, USA, pp. 222. [online] URL: http://books.google.com/books?id=rBXnBwAA QBAJ

Martínez-Fernández J, Chuvieco E, Koutsias N (2013). Modelling long-term fire occurrence factors in Spain by accounting for local variations with geographically weighted regression. Natural Hazards and Earth System Sciences 13 (2): 311-327. - doi: 10.5194/nhess-13-311-2013

Martínez J, Vega-García C, Chuvieco E (2009). Human-caused wildfire risk rating for prevention planning in Spain. Journal of Environmental Management 90 (2): 1241-1252. - doi: 10.1016/ j.jenvman.2008.07.005

Massada AB, Radeloff VC, Stewart SI, Hawbaker TJ (2009). Wildfire risk in the wildland-urban interface: a simulation study in northwestern Wisconsin. Forest Ecology and Management 258: 1990-1999. - doi: 10.1016/j.foreco.2009.07.0 51

McInerney D, San-Miguel-Ayanz J, Corti P, Whitmore C, Giovando C, Camia A (2013). Design and function of the European forest fire information system. Photogrammetric Engineering and Remote Sensing 79 (10): 965-973. - doi: 10.14358/PERS.79.10.965

Miller C, Ager AA (2013). A review of recent advances in risk analysis for wildfire management. International Journal of Wildland Fire 22 (1): 1-14. - doi: 10.1071/WF11114

Montiel-Molina C (2013). Comparative assessment of wildland fire legislation and policies in the European Union: towards a fire framework directive. Forest Policy and Economics 29: 1-6. doi: 10.1016/j.forpol.2012.11.006

Moreira F, Rego FC, Ferreira PG (2001). Temporal (1958-1995) pattern of change in a cultural landscape of northwestern Portugal: implications for fire occurrence. Landscape Ecology 16 (6): 557-567. - doi: 10.1023/A:1013130528470

Moreira F, Viedma O, Arianoutsou M, Curt T, Koutsias N, Rigolot E, Barbati A, Corona P, Vaz P, Xanthopoulos G, Mouillot F, Bilgili E (2011). Landscape-wildfire interactions in Southern Europe: implications for landscape management. Journal of Environmental Management 92:
2389-2402. - doi: 10.1016/j.jenvman.2011.06.028 Moreno JM, Vallejo VR, Chuvieco E (2013). Current fire regimes, impacts and the likely changes - VI: Euro Mediterranean. In: "Vegetation Fires and Global Change: Challenges for Concerted International Action" (Goldammer JG ed). White Paper, Global Fire Monitoring Center (GFMC), Kessel Publishing House, Remagen, Germany, pp. 115-131. [online] URL: http://www.fire.uni-freiburg.de/latestnews/Ve getation-Fires-Global-Change-UN-White-PaperGFMC-2013.pdf\#page $=116$

Moreno JM, Vázquez A, Veléz R (1998). Recent history of forest fires in Spain. In: "Large Forest Fires" (Moreno JM ed). Backhuys Publishers, Leiden, the Netherlands, pp. 159-185.

Moreno JM, Viedma O, Zavala G, Luna B (2011). Landscape variables influencing forest fires in central Spain. International Journal of Wildland Fire 20 (5): 678-689. - doi: 10.1071/WF10005

Oliveira S, Oehler F, San-Miguel-Ayanz J, Camia A, Pereira JMC (2012). Modeling spatial patterns of fire occurrence in Mediterranean Europe using multiple regression and random forest. Forest Ecology and Management 275: 117129. - doi: 10.1016/j.foreco.2012.03.003

Oliveira S, Pereira JMC, San-Miguel-Ayanz J, Lourenço $L$ (2014). Exploring the spatial patterns of fire density in southern Europe using geographically weighted regression. Applied Geography 51: 143-157. - doi: 10.1016/j.apgeog.2014.04.0 02

Openshaw S (1984). The modifiable areal unit problem. Concepts and Techniques in Modern Geography 38 (38): 41.

Palaiologou P, Kalabokidis K, Kyriakidis P (2013). Forest mapping by geoinformatics for landscape fire behaviour modelling in coastal forests, Greece. International Journal of Remote Sensing 34 (12): 4466-4490. - doi: 10.1080/014 31161.2013.779399

Pausas J, Fernández-Muñoz S (2012). Fire regime changes in the western Mediterranean Basin: from fuel-limited to drought-driven fire regime. Climatic Change 110 (1-2): 215-226. - doi: 10.1007/ s10584-011-0060-6

Pérez B, Cruz A, Fernández-González F, Moreno $J M$ (2003). Effects of the recent land-use history on the postfire vegetation of uplands in central Spain. Forest Ecology and Management 182 (1-3): 273-283. - doi: 10.1016/So378-1127(03) 00069-0

Perry JN, Dixon PM (2002). A new method to measure spatial association for ecological count data. Ecoscience 9 (2): 133-141. [online] URL: http://www.jstor.org/stable/42901477

Pezzatti GB, Bajocco S, Torriani D, Conedera M (2009). Selective burning of forest vegetation in Canton Ticino (southern Switzerland). Plant Biosystems 143 (3): 609-620. - doi: 10.1080/ 11263500903233292

Podur J, Martell DL, Csillag F (2003). Spatial patterns of lightning-caused forest fires in Ontario, 1976-1998. Ecological Modelling 164: 1-20. - doi: 10.1016/S0304-3800(02)00386-1

Pyne SJ, Andrews PL, Laven RD (1996). Introduction to wildland fire ( $2^{\text {nd }}$ edn). John Wiley and Sons Inc., New York, USA, pp. 769. [online] URL: http://www.cabdirect.org/abstracts/19970 604058.html

Rideout DB, Omi PN (1990). Alternate expres- sions for the economic theory of forest fire management. Forest Science 36 (3): 614-624. [online] URL: http://www.ingentaconnect.com/ content/saf/fs/1990/00000036/00000003/artoo 011

Rodrigues M, De La Riva J (2014). An insight into machine-learning algorithms to model humancaused wildfire occurrence. Environmental Modelling and Software 57: 192-201. - doi: 10.1016/ j.envsoft.2014.03.003

Rodrigues M, De La Riva J, Fotheringham S (2014). Modeling the spatial variation of the explanatory factors of human-caused wildfires in Spain using geographically weighted logistic regression. Applied Geography 48: 52-63. - doi: 10.1016/j.apgeog.2014.01.011

Salis $M$, Ager AA, Arca B, Finney MA, Bacciu V, Duce $P$, Spano D (2013a). Assessing exposure of human and ecological values to wildfire in Sardinia, Italy. International Journal of Wildland Fire 22 (4): 549-565. - doi: 10.1071/WF11060 Salis M, Ager AA, Finney MA, Arca B, Spano D (2013b). Analyzing spatiotemporal changes in wildfire regime and exposure across a Mediterranean fire-prone area. Natural Hazards 71 (3): 1389-1418. - doi: 10.1007/s11069-013-0951-0

San-Miguel-Ayanz J, Schulte E, Schmuck G, Camia A (2013). The European Forest Fire Information System in the context of environmental policies of the European Union. Forest Policy and Economics 29: 19-25. - doi: 10.1016/j.forpol. 2011.08.012

Santini M, Collalti A, Valentini R (2014). Climate change impacts on vegetation and water cycle in the Euro-Mediterranean region, studied by a likelihood approach. Regional Environmental Change: 1-14. - doi: 10.1007/s10113-013-0582-8 Seaman DE, Powell RA (1996). An evaluation of the accuracy of kernel density estimators for home range analysis. Ecology 77 (7): 2075-2085. - doi: 10.2307/2265701

Sebastián-López A, Salvador-Civil R, Gonzalo-Jiménez J, SanMiguel-Ayanz J (2008). Integration of socio-economic and environmental variables for modelling long-term fire danger in Southern Europe. European Journal of Forest Research 127 (2): 149-163. - doi: 10.1007/s10342007-0191-5

Syphard AD, Keeley JE, Brennan TJ (2011). Comparing the role of fuel breaks across southern California national forests. Forest Ecology and Management 261 (11): 2038-2048. - doi: 10.1016/ j.foreco.2011.02.030

Thompson MP, Calkin DE, Finney MA, Ager AA, Gilbertson-Day JW (2011). Integrated nationalscale assessment of wildfire risk to human and ecological values. Stochastic Environmental Research and Risk Assessment 25 (6): 761-780. doi: 10.1007/s00477-011-0461-0

Tsiourlis G, Andreadakis S, Konstantinidis P (2009). SITHON: a wireless network of in situ optical cameras applied to the early detectionnotification-monitoring of forest fires. Sensors 9 (6): 4465-4482. - doi: 10.3390/s90604465 Turco M, Llasat M-C, Von Hardenberg J, Provenzale A (2014). Climate change impacts on wildfires in a Mediterranean environment. Climatic Change: 1-12. - doi: 10.1007/s10584-014-1183-3 Vazquez A, Moreno JM (1998). Patterns of lightning-, and people-caused fires in Peninsular Spain. International Journal of Wildland Fire 8 
(2): 103-115. - doi: 10.1071/WF9980103

Vázquez A, Moreno JM (2001). Spatial distribution of forest fires in Sierra de Gredos (Centra Spain). Forest Ecology and Management 147 (1): 55-65. - doi: 10.1016/S0378-1127(00)00436-9 Viedma $O$ (2008). The influence of topography and fire in controlling landscape composition and structure in Sierra de Gredos (Central Spain). Landscape Ecology 23 (6): 657-672. doi: 10.1007/s10980-008-9228-5

Viedma O, Angeler DG, Moreno JM (2009). Landscape structural features control fire size in a Mediterranean forested area of central Spain. International Journal of Wildland Fire 18 (5): 575-583. - doi: 10.1071/WFo8030

Viedma O, Moity N, Moreno JM (2015). Changes in landscape fire-hazard during the second half of the $20^{\text {th }}$ century: agriculture abandonment and the changing role of driving factors. Agriculture, Ecosystems and Environment 207: 126140. - doi: 10.1016/j.agee.2015.04.011

Viegas DX, Bovio G, Ferreira A, Nosenzo A, Sol B (1999). Comparative study of various methods of fire danger evaluation in southern Europe. International Journal of Wildland Fire 9 (4): 235246. - doi: 10.1071/WF00015

Viegas DX, Allgöwer B, Koutsias N, Eftichidis C (2003). Fire spread and the urban wildland interface problem. In: Proceedings of the "International Workshop on Forest Fires in the Wildland-Urban Interface and Rural Areas in Europe: an integral planning and management challenge" (Xanthopoulos G ed). Athens (Greece) 15-16 May 2003. Mediterranean Agronomic Institute of Chania (MAICh), Hania, Greece, pp. 93-103. [online] URL: http://www.researchgate.
net/profile/Nikos_Koutsias/publication/2678347 80

Vilar Del Hoyo L, Isabel MPM, Vega FJM (2011). Logistic regression models for human-caused wildfire risk estimation: analysing the effect of the spatial accuracy in fire occurrence data. European Journal of Forest Research 130 (6): 983-996. - doi: 10.1007/s10342-011-0488-2

Worton BJ (1989). Kernel methods for estimating the utilization distribution in home-range studies. Ecology 70 (1): 164-168. - doi: 10.2307/ 1938423

Xystrakis F, Koutsias N (2013). Differences of fire activity and their underlying factors among vegetation formations in Greece. iForest - Biogeosciences and Forestry 6 (1): 132-140. - doi: 10.3832/iforo837-006 